more effective as contraceptives at the selected dosage. It may well be that the mode of action of low dosage progestogens in controlling fertility is less dependent on changes in cervical mucus and operates predominantly through other mechanisms. ${ }^{5-7}$ It is also possible that the time factor and duration of action may play a more significant part when lower dosages are employed. Norethisterone, norgestrol, and chlormadinone were very much more effective, although the pregnancy rates were considerably higher than reported by other observers. ${ }^{3-10}$ Dr. Mears is of the opinion that the majority of pregnancies occur in the early cycles, and that her figures for this study are therefore compatible statistically with the data published elsewhere.

In this connexion I would like to present some preliminary data on a personal study with norgestrol in a dosage of $0.05 \mathrm{mg}$. daily for fertility control. Information has been obtained over 800 cycles of medication. There have been no pregnancies. Four women have withdrawn from the study; three in order to enlarge their families and one on my instructions owing to irregular and persistent heavy bleeding. The three women who wished to become pregnant all conceived within two months of stopping norgestrol. The dosage instructions were somewhat different from those usually employed and may be of some interest.

The patients visited the clinic any day of their cycle and following examination were told that the tablets must be taken daily and may be relied on from the first day, but some four hours should be allowed from the time of taking the tablet and coital activity restricted to 14 hours from the time of medication. With continued use this restriction is gradually relaxed. It is pointed out that day 1 bears no relation to the cycle day, and some $20 \%$ of patients started the midication around the time of midcycle. The rationale is based on some previous studies using migestrol acetate as a precoital pill. The mean parity of the women in the study is over two.

The precise mechanism of action of minidose progestogens is not known, but whether it be effects on cervical mucus, alterations in ovum transport, endometrial nidation, changes in corpus luteum function, ${ }^{11}$ or progesterone metabolism, or interference with sperm capacitation, certainly it would appear that some antifertility effect takes place rapidly. The onset of action and duration of effect may be fairly critical during the early months of medication and may account for a number of pregnancies observed by some investigators in the early cycles of treatment.-I am, etc.,

\title{
Penn, Bucks.
}

$$
\text { H. J. E. Cox. }
$$

\footnotetext{
REFERENCES

1 Cox, H. J. E. fournal of Faculty of Medicine, Baghdad, 1967, 9, 119.
Mason, B. A., Cox, H. J. E., Mason, D. W.,
and Grant. V., Postgraduate Medical fournal, and Grant, V., Postgraduate Medical fou

- Carey, H., personal communication, 1967 . Swyer, G. I. M., Postgraduate Medical fournal 1967, 43, December Supplement

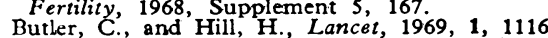
Butler, C., and Hill, H., Lancet, 1969, 1, 1116.
Bennett, J. P., Vickery, B. H., and Dorfman,
R. I., Society for Study of Fertility, Annual Conference, Bristol, 1969

- Martinez-Manautou, J., Giner-Velasquez, J., Cortes-Gallegos, V., Aznar, R., Rojas, B.,
Guitterez-Najar, A., and Rudel, H. W., British Guitterez-Najar, A., and Rudel,

- Zañartu, J., Rodriguez-Moore, G., Pupkin, M. Salas, O., and Guerrero, R., British Medical fournal, 1968, 2, 263.

10 Foss, G. L.. Svendsen, E. K., Fotherby, K., 4.489.
Fotherby, K., Svendsen, E. K., and Foss

Fotherby, K., Svendsen, E. K., and Foss,

1968. Supplement 5, 155 .
}

\section{Fibrin Degradation Products}

SIR,-In their recent article Dr. John Bonnar and others (19 July, p. 137) found that the levels of fibrin/fibrinogen degradation products (F.D.P.) remained unchanged during normal pregnancy. Previously Woodfield et al. ${ }^{1}$ had reported a progressive rise during the second and third trimester. In my opinion, this reported difference may be due to the anti-human fibrinogen serum used in the haemagglutination inhibition immuno-assay (H.I.I.) technique ${ }^{2}$ which they utilized to measure F.D.P.

Both groups of authors used a Hoechst Pharmaceuticals anti-serum to fibrinogen, produced in rabbits, but as the two papers were published some six months apart it seems unlikely that they had both used the same batch of anti-serum. Of the many peptide fragments produced by the degradation of fibrinogen by plasmin, only two named fragments, $D$ and $E$, react with an anti-fibrinogen serum. ${ }^{3}$ Nussenzweig et al. showed that different anti-fibrinogen sera prepared in rabbits against the same human fibrinogen contained different amounts of anti-fragment $\mathrm{D}$ and anti-fragment $\mathrm{E}$. As the H.I.I. method of estimating F.D.P measures the "sum" of levels of fragments $D$ and $E$, it is not surprising that different antisera give different values for F.D.P. in a serum from a given patient.

The difference between Bonnar's and Woodfield's results could be explained thus: (a) a rise of either D or E occurred, but Bonnar's anti-serum contained only a small amount of antibodies reacting with this fragment and hence his group failed to show a rise of F.D.P. as pregnancy progressed, or (b) a rise of either D or E occurred, but the levels of the other fragment fell, and as Woodfield's anti-serum contained only a small proportion of antibodies to the fragment whose level was falling, their estimation of total F.D.P. showed a rise.

With the availability of a commercial kit for estimating F.D.P. (Burroughs Wellcome) it is essential that the proportion of antifragment-D and anti-fragment $E$ should remain constant from one batch of antiserum to the next. If this is not ensured, we shall have a situation exactly analogous to that which, until recently, prevailed in the field of anticoagulant control, where the results of the one-stage prothrombin time performed in different laboratories were by no means comparable.-I am, etc.,

\section{Department of Haematology,
Royal Infirmary, Royal Infi.
Bristol.}

\section{REFERENCES}

1 Woodfield, D. G., Cole. S. K., Allan, A. G. E., and Cash, f. D., British Medical fournal, 1968, 4,665 .

Mersky, C., Kleiner G. J., and Johnson, A. J., Nussenzweig, V., and Seligmann, M., Revue d'Hématology. 1960, 15, 451 .

Nussenzweig, V., Seligmann, M., and Grabar, P.,
Annales de l'Institut Pasteur, 1961, 100, 377.

\section{Aetiology of Pre-eclampsia}

SIR,-In reply to $\mathrm{Mr}$. G. J. Sophian (26 July, p. 241) I would like to point out that an intravascular coagulation theory is the only way of explaining the immuno-fibrin that is demonstrated in the swollen endothelial cells. Vassalli $i^{\mathrm{l}}$ has shown by infusing. rabbits with thromboplastin that a whole spectrum of changes can be produced from "endotheliosis," the equivalent of preeclampsia, to frank intraglomerular thrombi as in eclampsia. Similar findings in rats were found by Margaretten et al. ${ }^{2}$

I cannot agree that this "endotheliosis" is a feature of ischaemia per se: this is a reaction of the endothelium to the presence of fibrin, antigen-antibody complexes, and other macromolecules. This is why it is also a feature of acute nephritis and lupus nephritis, and in fact nephrosclerosis can be produced either by platelet embolization" or again as a result of intravascular coagulation. ${ }^{4}$ The placenta or trophoblast cells seem to be the only likely source of the thromboplastin that triggers the coagulation process, and I cannot explain post-partum eclampsia other than as a result of the retention of fragments of decidua. ${ }^{5}$ a A procoagulant substance has been isolated from human post-partum serum ${ }^{7}$ and renal lesions of toxaemia can be produced in the rat by the injection of placental extract. ${ }^{8}$ In the paper that we quoted infarcts were found in $67 \%$ placentae in toxaemia. ${ }^{\circ}$

However, I agree with Mr. Sophian that this theory does not explain the hypertension, for which other factors must be invoked and among them the utero-renal reflex. There is accumulating evidence for an association between intravascular coagulation in the kidney and the genesis of renal hypertension. It is true that profound defibrination results in shock and hypotension because of the obstruction of the microcirculation and the vasodilator action of thrombin, but this does not apply to subacute intravascular coagulation.

I anticipate that in the near future somebody will report on the prevalence of microangiopathic red cell fragmentation in preeclampsia and eclampsia, ${ }^{10}$ on the levels of fibrin products in the circulation, and perhaps also on actual fibrinogen catabolic rates.I am, etc.,

\section{Royal Victoria Infirmary,
Newcastle upon Tyne.}

E. N. WARDLE.

\section{REFERENCES}

1 Vassalli, P., Simon, G., and Roullier, C., Nature, 1963, 199, 1105

Margaretten, W., Csavossy, I., and McKay, D. G., Blood, 1967, 29, 169

Moore, S., and Mersereau, W. A., Archives of Pathology, 1968, 85, 623.

Brentjens, J. R. H., Vreeken, J., FeltkampVroom, T., and Helder, A. W., Acta Medica Scandinavica, 1968, 183, 203

Hegetschweiler, W ische Wochenschrift, 1956, 86, 137.

Hunter, C. A., jun., Howard, W. F., and McCormick. C. O., jun., American fournal of Obstetrics and Gynecology, 1961, 81, 884.
Teger-Nilsson, A. C., Scandinavian fournal of
Clinical and Laboratory Investigation, 1967, $\mathbf{2 0}, 339$.

8 Irino, T., Okuda, T., and Grollman, A., American fournal of Pathology, 1967, 50, 421 . Wentworth, P., American fournal of Obstetrics
and Gynecology, 1967, 99, 318. Baker. L. R. I., Rubenberg, M. L., Dacie, J. V., and Brain, M. C., British fournal of
Haematology, 1968, 14, 617 .

\section{Porton Jet Injector}

SIR,-In the hope of making full use of our Porton jet injector, I have investigated applications suggested by the suppliers which, besides influenza, propose other mass inocu- 